\title{
Critical Factors in Repayment of Constituency Youth Enterprise Scheme in Kirinyaga Central District, Kenya
}

\author{
Anne Murathi, John Okello Weda \\ Department of Education and External Studies, University of Nairobi, Nairobi, Kenya
}

Email address:

annemurathi@yahoo.com (A. Murathi),wedaokello@gmail.com (J. O. Weda)

To cite this article:

Anne Murathi, John Okello Weda. Critical Factors in Repayment of Constituency Youth Enterprise Scheme in Kirinyaga Central District, Kenya. Journal of Finance and Accounting. Vol. 3, No. 2, 2015, pp. 19-27. doi: 10.11648/j.jfa.20150302.11

\begin{abstract}
YEDF continues to lend more money through C-YES component that is meant to be a revolving fund and if the trend continues there may be no more money to lend in the near future. However, factors affecting its repayment have not been studied adequately. The purpose of this research was to find out factors affecting the repayment of Constituency Youth Enterprise Scheme (C-YES) in Kirinyaga Central District. The study was guided by three objectives; to investigate the relationship between availability of resources on repayment of Constituency Youth Enterprise Scheme Loan (C-YES) in Kirinyaga Central District, to determine how time taken between application and receiving of funds affect the repayment of constituency Youth Enterprise Scheme Loan (C-YES) in Kirinyaga Central District and to determine how amount of loan given affect the repayment of Constituency Youth Enterprise Scheme Loan (C-YES) in Kirinyaga Central District. The researcher used descriptive survey. The study employed both stratified random sampling and simple random sampling. Data was collected using closed and open-ended questionnaires. These questionnaires were administered by the researcher. The data was then analyzed by use of frequency distribution tables and pie charts. The study revealed that Constituency Youth Enterprise Scheme (C-YES) is faced with numerous challenges in its attempt to empower the youths and sustain itself in repayment. Inadequate funding was cited as a factor contributing to any economic activity not to realize its full potential and this negatively affects it.
\end{abstract}

Keywords: Socio-Cultural Factors, Consumer Choice of Commercial Banks, Non-Governmental Organizations, Nakuru Town

\section{Introduction}

\subsection{Background of the Study}

There is a rapidly growing population of the youth that not only exerts greater pressure on employment but also poses a serious socio-economic problem to policy makers (UNDP, 2000). Unfortunately many are not meaningfully engaged in National Development due to lack of employment opportunities and high unemployment remains one of the greatest challenges to Africa's development and hence a major concern to policy makers and other stakeholders in Africa (ILO, 2008).

In South Africa, the Umsobomvu Youth Fund (UYF) was established and capitalized by the South African government to facilitate and promote the creation of jobs and skills development and transfer among young South Africans between the ages of 18 and 35 years. However, the fund is faced with challenges that results in clients defaulting or dropping from the loan agreement. The causes for these challenges are not yet clear, nor is it possible to determine during the application stage or during the implementation stage that clients will experience problems that would negatively impact their ability to pay off their loans (UYF Strategic Plan, 2001).

In Botswana, having realized that Botswana's population is dominated by young people (67.6\%) who are mostly affected by a variety of challenges, the government came up with the initiative of introducing Citizen Entrepreneurial Development Agency (CEDA) Young Farmers Fund (CYFF). It was established to reverse some challenges facing Botswana such as poverty, unemployment, rural-urban migration, low participation of youth in agriculture, low contribution of agriculture to GDP. The loan is for all Botswana citizens aged between 18-40 years and attracts an interest rate of 5\%. However, there is still the challenge of default (CYFF Strategic Plan, 2001).

The Youth Enterprise Development Fund (YEDF) was conceived by the Kenyan Government in June 2006 as one of the strategies of addressing youth unemployment. The fund 
was officially launched by His Excellency President of Kenya on $1^{\text {st }}$ February 2007 and transformed into a state corporation on $11^{\text {th }}$ May 2007 (Youth Enterprise Development Fund Strategic Plan year 2008-2011).
Under the guidance of the youth officers, the fund has lent out through the C-YES a total of Ksh. 376,923,810 countrywide to 8,586 groups distributed as per the summary in table 1.1 as at $30^{\text {th }}$ October 2009 (YEDF Report, 2009).

Table 1.1. Provinces and their Repayment analysis.

\begin{tabular}{|c|c|c|c|c|}
\hline Province & No. Of. Youth Groups & Total Disbursement & Amount Repaid & Outstanding Balance \\
\hline Central & 1,107 & $49,412,796.00$ & $13,682,307.40$ & $35,730,488.60$ \\
\hline Coast & 802 & $37,946,127.00$ & $5,208,367.00$ & $32,737,760.00$ \\
\hline Eastern & 1,503 & $68,666,887.00$ & $21,358,696.00$ & $47,308,191.00$ \\
\hline $\mathrm{N} /$ Eastern & 469 & $18,845,000.00$ & $2,362,798.00$ & $16,482,202.00$ \\
\hline Rift valley & 1,981 & $86,257,529.00$ & $20,967,897.85$ & $65,289,631.15$ \\
\hline Western & 1,094 & $42,746,865.00$ & $6,032,862.33$ & $36,714,002.67$ \\
\hline Nyanza & 1,299 & $58,649,607.40$ & $10,694,089.70$ & $47,955,517.70$ \\
\hline Nairobi & 331 & $14,398,999.50$ & $3,425,067.00$ & $10,973,931.50$ \\
\hline TOTAL & 8,586 & $376,923,810.90$ & $83,732,085.88$ & $293,191,724.62$ \\
\hline
\end{tabular}

Source: YEDF Report, (2009).

It can be noted from table 1.1 that the repayment of the loan is poor and if the trend continues, the fund may not revolve as it was intended to. This may lead to its eventual total collapse.

\subsection{Research Objectives}

This study was guided by the following objectives:

(i) To find out how availability of resources affect the repayment of Constituency Youth Enterprise Scheme Loan (C-YES) in Kirinyaga Central District.

(ii) To determine how time taken between application and receiving of funds affect the repayment of constituency Youth Enterprise Scheme Loan (C-YES) in Kirinyaga Central District.

(iii) To determine how amount of loan given affect the repayment of Constituency Youth Enterprise Scheme Loan (C-YES) in Kirinyaga Central District.

\subsection{Research Questions}

This study sought to answer the following research questions:

(i) How does availability of resources affect the repayment of Constituency Youth Enterprise Scheme Loan (C-YES) in Kirinyaga Central District?

(ii) How does time taken between application and receiving of funds affect the repayment of Constituency Youth Enterprise Scheme Loan (C-YES) in Kirinyaga Central District?

(iii) How does the amount of loan given affect the repayment of Constituency Youth Enterprise Scheme Loan (C-YES) in Kirinyaga Central District?

\subsection{Significance of the Study}

The findings of the research will benefit the management in YEDF for it will provide part of the body of evidence necessary for revision of policies regarding the administering of YEDF. Again, the government, as a prime mover of the fund through budgetary allocation, will benefit from the findings of the research especially in policy matters on how to improve and modify business training programmes to suit, not only the entrepreneurial challenges of the day, but also anticipate more in a fast-evolving technological world in business. The findings will also benefit the donors and other stakeholders who may want to fund youth activities in the model of YEDF or in grants in implementation of their programmes especially in monitoring and evaluation of their credit facilities for sustainability purposes. The findings of the research will benefit the youths by being conscious of the socio-economic factors hindering the smooth repayment of $\mathrm{C}$-YES. Again, the research will add value to the body of knowledge and understanding of Constituency Youth Enterprise Scheme Loan (C-YES). This will be beneficial to researchers who may want to research more on this area.

\subsection{Conceptual Framework}

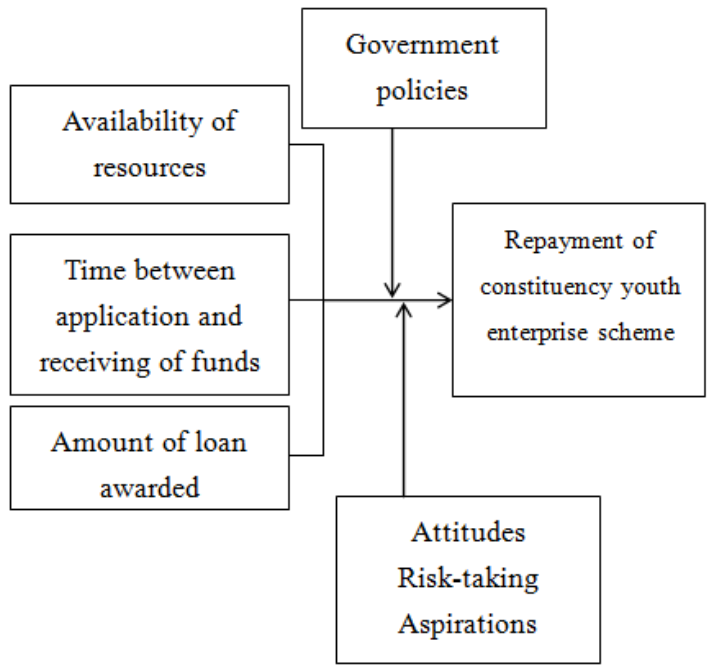

Figure 1. Conceptual Framework 
The main objective of the study is to analyze the factors affecting the repayment of Constituency Youth Enterprise Scheme in Kirinyaga Central District. The research shall adopt the conceptual framework illustrated in the figure 1 shown below. The dependent variables identified are availability of resources, follow-up measures and time taken between applications and receiving the loan. These variables were studied to identify their significance to achieve successful repayment of C-YES as illustrated in the diagram below.

\section{Literature Review}

\subsection{Youth Unemployment}

A 2005 study by the United Nations Economic commission for Africa stated that the employment rate among the African youth was 21 percent compared with a rate of 14 percent for the rest of the world. It also indicated that despite a wealth of human and natural resources, a lack of sustained economic growth in many African countries has diminished the employment prospects available for young people (UNDP, 2000).

According to Samuel (2009) the number of unemployed youth in Kenya could rise to 14 million over the next seven years. It is feared that this high number of jobless youths could spark off a peoples' revolution if it is not tamed. Though the specific data of youth unemployment might not be available, barely 125,000 are annually absorbed into formal employment which today has nearly 1.8 million employees. The informal sector, which has about eight million workers, absorbs the most. Kenya is not alone, of the six billion people in the world; nearly one billion comprises the youth and over 850 million of these live in developing countries. There are calls for the Kenyan Government to map its human resource because this will enable her tells which skill is found where and direct special programmes to that area.

Akama (2009) notes that most projects by the government are introduced without consulting the youth or sensitizing them about the projects. He adds that it has been argued that the Government's action to tame the unemployment monster has been slow but noticeable. The creation of the Ministry of Youth Affairs in 2005 is an indication that it appreciates the problem.

The Youth Enterprise Development Fund (YEDF) came legally into operation on $8^{\text {th }}$ December 2006 through legal notice No. 167. It was transformed into a state corporation on $11^{\text {th }}$ May 2007 through legal notice No. 63. Its main purpose was to create employment for the youth of Kenya and a vision of a sustainable and growing fund economically empowering Kenyan youth (YEDF Strategic plan, 2008-2010).

\subsection{Factors Affecting Loan Repayments}

According to Vivek, (2007) the problem of recovery of overdue loans depends upon the respective nature of loans and cites the following as some of the main factors affecting loan repayment. To start with, improper selection of an entrepreneur where two major criterions namely the intention to repay and the capacity to repay should be properly dealt with in credit evaluation. The entrepreneurs who have the willingness, capabilities, qualities and the requisite expertise for successfully setting up and running an enterprise should be identified with proper prudence and judiciousness. This is the best way of safeguarding the investment of a financier thereby ensuring proper and timely repayment. Secondly, deficient analysis of project viability is an important reason for proper recovery of loan attributable to wrong selection of projects. Success of any project depends upon the viability of the project, and the viability in turn, depends upon the easy availability of raw material, transportation, skilled labor, communication facilities, and market among others. If any of the above is not easily available to the entrepreneur, it results in an increase in the cost of the project and also in delay of production. This inevitably affects the repayment of loans.

Khare (2007) says that inadequacy of collateral security/Equitable mortgage against loan affects repayment. Collateral security by way of mortgage of immovable property or other fixed assets, thereby creating a charge, trains the mind of the borrower to be prepared to pay the dues to the lenders. But when he is free from this fear of losing his encumbered asset in the event of his/her defaulting in the payment of dues, he/she often takes the liberty, and tends to weigh the pros and cons vis-a-vis default. Security against loan, though at times may fall harsh on the borrower, serves a worthwhile purpose in that it creates promoters' stake in the borrower and thus, discipline the borrower to be more committed in paying the dues to lenders.

\subsubsection{Availability of Resources and Follow-up Measures}

Khare (2007) cites that lack of follow up measures and resources to follow up affects loan repayment. Follow up measures taken regularly and systematically keep the borrowing unit under constant vigil of the lender. Many ills can be checked through such follow up measures by keeping the borrowing units on their alertness and guiding them to rectify their mistakes in the first opportunities or extending them a helping hand in tiding over their tight times. Normally, such close follow-up programmes are conspicuous by their absence. In the result, the borrowing units not only ignore payment of their dues to the lenders but also often tread on wrong tracks. Performance of borrowing units, if carefully and systematically monitored through regular inspections by scrutiny of returns, annual balance sheet and inspection of site, can be significantly improved. Naturally, such inspections prevent the borrowers from deviating from the terms and conditions of the loan or from diverting any fund for purpose other than those earmarked in the sanction letter and keep the financial health of the units in good order.

Gupta (2007) adds that fluctuations in statutory regulations and norms affect loan repayment. Certain 
unforeseen, unpredictable and unexpected fluctuations in the statutory regulations such as change in the exercise rates, commercial tax, electricity tariff and other revenue tools of the government tend to throw the entire planning of the industrialist out of gear. It has been observed that these fluctuations are of such a magnitude and are so unpredictable as to be beyond the comprehension of the most skeptic and apprehensive of entrepreneur. In order to cope with these unforeseen variations, which force the entrepreneur to put additional burden on his financial resources, the natural and convenient remedy that comes to his/her mind is to delay the repayment of the loan.

\subsubsection{Time Taken Between Application and Receiving of Funds}

According to Abraham (2008) time taken between application and receiving of funds can affect loan repayment. Occasions are not few when there develops a tendency on the part of the financiers to paint a rosy picture of the project at the time of appraisal. If the sanctioning authority is guided by considerations of personal interests, many things may happen. The break-even point of a project may be shown at an unrealistically low level of operation, or profitability may be shown at an unduly high level just to brighten the chances of acceptability of the project by the lender, or cash inflow may be shown in an unduly optimistic manner and therefore, Debts Service Coverage Ratio (DSCR) worked out incorrectly, fixing unrealistically high installments and conservative schedule of repayments. These inner pulls and pressures may find reflection in fixing excessive amounts of installments in order to show an early period of repayment. The borrower at this stage finds himself in an unenviable position of a 'yes master' and nods his/her head at whatever conditions are attached or whatever repayment schedule is fixed in all probability, covering up his/her design to evade payment of the future dues. The real problem surfaces when repayment of installments/interest falls due and the borrower conveniently and blissfully ignores calls for clearance of the said dues not so much due to his/her intention to defraud the loans as due to him already bleeding white to keep his/her concern going. He also adds that a certain proportion of default can be attributed to natural calamities such as floods, earthquakes, storms etc. prima-facie this would seem to be a factor beyond human control. A more detailed insight, would however, suggest that certain precautionary preventive measures such as proper meteorological and topographical analysis of the industrial site can go a long way in reducing this element of risk. Natural calamities not only affect the unit directly but also exert additional burden on the government in terms of relief measures, waivers etc. A further fraction, albeit nominal, is of such borrowers who tend to take undue advantage of such natural calamities in order to avoid repayment, thereby increasing the magnitude of default.

\subsubsection{Government Policies}

Omino (2005) says that provisions of financial services to the low-income households and micro and small enterprises
(MSEs) provide an enormous potential to support the economic activities of the poor and thus contribute to poverty alleviation. Widespread experiences and research have shown the importance of savings and credit facilities for the poor and MSEs. This puts emphasis on the sound development of micro finance institutions as vital ingredients for investment, employment and economic growth. The potential of using institutional credit and other financial services for poverty alleviation in Kenya is quite significant. About 18 million people or $60 \%$ of the population are poor and mostly out of the scope of formal banking services (National Micro and Small Enterprise Baseline Survey of 1999).

The Government of Kenya recognizes that greater access to and sustainable flow of financial services, particularly credit to the low-income households is critical to poverty alleviation. Therefore, an appropriate policy, legal and regulatory framework to promote a viable and sustainable system of micro finance in the country has been developed via the proposed Deposit Taking Micro Finance Bill. In drafting the bill, the Government has consulted with stakeholders to get their views on the best way to create the required enabling environment for the micro finance sub-sector. In addition, full-fledged micro finance units have been established in the Ministry of Finance (the Treasury) and the Central Bank of Kenya to formulate policies and procedures to address the challenges facing micro finance institutions, especially in the rural areas and to build a database to facilitate better regulation and monitoring their operations (Omino, 2005).

Gupta, (2007) says that various state Governments have enacted laws of recovery of dues in pursuance of the Talwar committee recommendations but enforcement of these laws has remained dismally fruitless. Siddiqui (2008) suggests that the simple solution of recovering default loan is by enacting more strong law

\subsection{Government Policies as on Government Micro- Credit}

Omino (2005) says that provisions of financial services to the low-income households and micro and small enterprises (MSEs), provide an enormous potential to support the economic activities of the poor and thus contribute to poverty alleviation. Widespread experiences and research have shown the importance of savings and credit facilities for the poor and MSEs. This puts emphasis on the sound development of micro finance institutions as vital ingredients for investment, employment and economic growth. The potential of using institutional credit and other financial services for poverty alleviation in Kenya is quite significant. About 18 million people or $60 \%$ of the population are poor and mostly out of the scope of formal banking services (National Micro and Small Enterprise Baseline Survey of 1999).

The Government of Kenya recognizes that greater access to and sustainable flow of financial services, particularly credit to the low-income households is critical to poverty alleviation. Therefore, an appropriate policy, legal and regulatory framework to promote a viable and sustainable system of micro finance in the country has been developed 
via the proposed Deposit Taking Micro Finance Bill. In drafting the bill, the Government has consulted with stakeholders to get their views on the best way to create the required enabling environment for the micro finance sub-sector. In addition, full-fledged micro finance units have been established in the Ministry of Finance (the Treasury) and the Central Bank of Kenya to formulate policies and procedures to address the challenges facing micro finance institutions, especially in the rural areas and to build a database to facilitate better regulation and monitoring their operations (Omino, 2005).

Gupta, (2007) says that various state Governments have enacted laws of recovery of dues in pursuance of the Talwar committee recommendations but enforcement of these laws has remained dismally fruitless. Siddiqui (2008) suggests that the simple solution of recovering default loan is by enacting more strong law

\section{Research Methodology}

\subsection{Research Design}

In this study, survey research design was used. According to Mugenda and Mugenda (2003) survey research could be descriptive, exploratory or involving advanced statistical analysis. The researcher used descriptive survey. Descriptive research determines and reports the way things are and attempts to describe such things as possible behavior attitudes, values and characteristics. Schindler and Coopers (2003) says that descriptive studies are structured with clearly stated investigative questions. Descriptive studies serve a variety of research objectives including description of phenomena or characteristics associated with subject population, estimate of proportion of population that have similar characteristics associated and discovery of association among different variables. Survey research design was chosen in this study because the researcher aimed at identifying the prevalence of factors in successful repayment of C-YES and to establish any relationship between the factors identified.

\subsection{Target Population}

The target population consisted of all the 58 youth groups funded through Constituency Youth Enterprise Scheme Loan (C-YES) in Kirinyaga Central District. The researcher targeted the group officials, members and the six employees of the Ministry of Youth Affairs and Sports working in Kirinyaga District.

\subsection{Sample Size and Sampling Technique}

Sampling is the process of selecting a number of individuals or objectives from a population such that the selected group contains elements representative of the characteristics found in the entire group (Mugenda \& Mugenda, 2003). The study used probability sampling technique. All categories of employees of the Ministry of Youth Affairs and Sports and group members were sampled. The study employed both stratified random sampling and simple random sampling. Stratified random sampling was suitable in this case because the population was divided into different strata or sub groups. The aim of stratified sampling was to achieve an even representation of the subgroups of the population in the selected sample (Mugenda \& Mugenda, 2003). In this study, the population was stratified into chairmen of groups, secretaries, treasurers and members. The researcher targeted $20 \%$ of the population although in descriptive study $10 \%$ of accessible population is enough (Mugenda \& Mugenda, 2003). This is summarized in table 3.1 .

Table 3.1. Sample Size

\begin{tabular}{llll}
\hline Category & Number In Category & Proportion Of Population & Sample Size \\
\hline MOYAS Staff & 6 & $90 \%$ & 5 \\
Group Chairpersons & 60 & $20 \%$ & 6 \\
Group Secretaries & 60 & $20 \%$ & 6 \\
Group Treasurers & 60 & $20 \%$ & 6 \\
Group Members & 400 & $20 \%$ & 80 \\
Total & & & 101 \\
\hline
\end{tabular}

\subsection{Methods of Data Collection}

The researcher carried out a pilot study of a selected sample to test the validity of the research instruments so that the right information could be obtained. Data was collected using closed and open-ended questionnaires. These questionnaires were administered by the researcher with the help of research assistants to the respondents on a drop and collect later basis. Because of its descriptive nature, the use of the technique was more economical and providing a safe basis for generalization (Kothari, 2004). There were two sets of questionnaires whereby one was administered to the youth groups to solicit information on the effects of the Constituency Youth
Enterprise Scheme (C-YES) on their day to day activities while the other one to the Ministry of Youth Affairs and Sports employees to solicit information on how they administer Constituency Youth Enterprise Scheme (C-YES) in their areas of jurisdiction.

\subsection{Validity and Reliability of the Research Instrument}

According to Mugenda and Mugenda (2003) validity is the accuracy and meaningfulness of inferences, which are based on the research results. It is the degree to which results obtained from the analysis of the data actually represent the phenomenon under study. Content validity was used. The 
researcher used her supervisors who were professionals and experts in research who fine-tuned the instrument. This ensured that the measures included an adequate and representative set of items that tapped the dimension and elements of concepts under study. The researcher also gave a professional in the field of micro-credit and requested her to access what concept the instrument was trying to measure and determine whether the set of items accurately represented the concept under study.

According to Mugenda and Mugenda (2003), reliability is a measure of the degree to which a research instrument yields consistent results or data after repeated trials. This was measured through test-retest technique, where the questionnaire was administered to a group of individuals with similar characteristics as the actual sample. The test was repeated after one week. The Spearman's Rank Correlation Coefficient was used to compute the correlation of the results of the two tests. A correlation coefficient of 0.7 was obtained. The objective was to establish if the instrument was consistent and stable in measuring what it was intended to measure. It was also used to establish the appropriateness and meaningfulness of inferences, conclusions, and decisions made on the basis of the tests scores to what the study intended to achieve.

\subsection{Data Collection Procedures}

A research permit was obtained. The researcher did data collection with the help of two research assistants who were trained and the actual collection of data took two weeks. Primary data was obtained from group officials and members. Secondary data was obtained from existing literature. Before undertaking the research in the field, an informed consent was obtained from the respondents. This was to allow the subjects to participate on voluntarily basis. The aims and objectives of the research were explained and expounded properly by the researcher, before and after undertaking the research as this would help in attaining an informed consent from the subjects (respondents).

\subsection{Data Analysis}

The raw data collected was first pre-processed. This included editing of data to detect errors and omissions and correct where possible. This involved a careful scrutiny of the completed questionnaires to ensure that the data was accurate, consistent with all facts gathered and uniformly entered.

The researcher then coded the data for efficiency in order to reduce the several replies to a small number of classes. Finally, the data was classified on the basis of common characteristics and attributes. After the mass of raw data were assembled, they were tabulated in form of statistical tables in order to allow further analysis. This in turn facilitated the summation and the detection of errors and omissions. The data was then analysed by use of frequency distribution tables. This was facilitated by the use of computer software for statistical analysis which is Statistical Package for Social Sciences (SPSS).

\section{Discussion}

\subsection{Performance of Joint Loan Board Schemes in Kenya}

Table 4.1. Performance of Joint Loan Board Schemes in Kenya (2000-2004).

\begin{tabular}{lll}
\hline Financial year & Loan Disbursed (Ksh) & Amount recovered (Ksh) \\
\hline $2000 / 01$ & $23,684,000.00$ & $17,438,003.83$ \\
$2001 / 02$ & $5,385,000.00$ & $717,455.65$ \\
$2002 / 03$ & $1,336,557.00$ & $14,215,918.22$ \\
$2003 / 04$ & $18,585,000.00$ & $15,431,083.18$ \\
$2004 / 05$ & $21,227,000.00$ & $11,543,646.59$ \\
Total & $90,217,577.00$ & $73,345,107.47$ \\
\hline
\end{tabular}

Source: Joint Loan Boards Scheme M\&E of Joint Loan Boards Report, 2005

It can be noted from the table that there are huge outstanding balances that are likely to adversely affect the board.

\subsection{Rural Enterprise Fund Outstanding Balances}

Table 4.2. Rural Enterprise Fund Outstanding Balances.

\begin{tabular}{lll}
\hline Final year & Cumulative repayment (Ksh) & Outstanding (Ksh) \\
\hline $1995 / 96$ & $1,309,020.50$ & $4,482,072.00$ \\
$1996 / 97$ & $1,467,543.70$ & $6,625,890.00$ \\
$1997 / 98$ & $1,467,923.10$ & $6,805,901.60$ \\
$1998 / 99$ & $1,566,296.30$ & $7,400,312.10$ \\
$1999 / 00$ & $153,682.60$ & $6,647,900.60$ \\
$2000 / 01$ & $256,284.60$ & $8,821,774.60$ \\
TOTAL & $6,220,750.8$ & $40,783,850.9$ \\
\hline
\end{tabular}

Source: Compiled from Rural Enterprise Fund Records: Uasin Gishu District.

From table 4,2 above, it is clear that there is poor repayment of the fund

\subsection{Causes of Default among Defaulters}

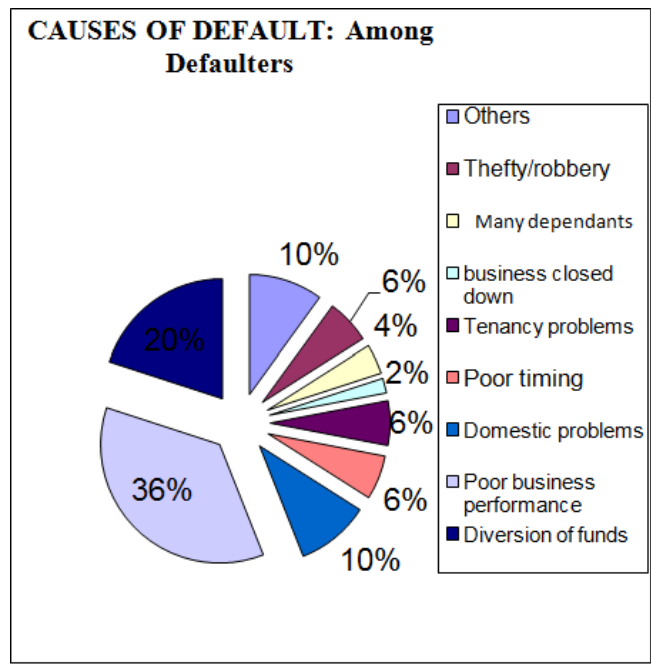

Figure 4.1. Causes of Default among Defaulters

Source: Wakuloba ( 2008) 


\subsection{Repayment of the Constituency Youth Enterprise Scheme}

Respondents were asked to comment about the repayment of the Constituency Youth Enterprise Scheme (C-YES). 80.0\% of the respondents indicated that the repayment of the C-YES was below average, while $20.0 \%$ of the respondents indicated that it was not up to date as shown in table 4.3. This indicates that there is a problem in the repayment of C-YES. This problem requires to be addressed in order to make the C-YES sustainable.

Table 4.3. Comments on Repayment of the Constituency Youth Enterprise Scheme.

\begin{tabular}{lll}
\hline Comments & Frequency & Percentage (\%) \\
\hline Below average & 4 & 80.0 \\
Not up to date & 1 & 20.0 \\
Total & 5 & 100 \\
\hline
\end{tabular}

\subsection{Factors that Hinder Repayment of C-YES Among Youth Groups}

From table 4.4 its clears that most of the factors hinder the repayment of loans among youth groups which results to the poor repayment rate of the C-YES.

Table 4.4. Factors that Hinder Repayment Among Youth Groups.

\begin{tabular}{lll}
\hline Factors that Hinders Repayment of & Frequency & Percentage (\%) \\
\hline C-YES & 28 & 27.6 \\
Politics & 12 & 11.8 \\
Attitude of members & 2 & 2.0 \\
Trust among members & 2 & 2.0 \\
Planning of activities & 1 & 1.0 \\
Competition & 8 & 7.9 \\
Coordination of activities & 16 & 15.9 \\
Management of the group & 15 & 14.9 \\
Training of members & 9 & 8.9 \\
Management & 4 & 4.0 \\
Economic situation & 3 & 3.0 \\
Mobility and commitment of members & 1 & 1.0 \\
New ways of doing business & 101 & 100.0 \\
Total &
\end{tabular}

\subsection{Factors Contributing to High Default Rate in C-YES}

Table 4.5. Factors Contributing to High Default Rate in C-YES According to Youth Officers.

\begin{tabular}{|c|c|c|}
\hline Factors contributing to high default rate & Frequency & $\begin{array}{l}\text { Percentage } \\
(\%)\end{array}$ \\
\hline Group disintegration & 1 & 20.0 \\
\hline Lack of resources & 4 & 80.0 \\
\hline $\begin{array}{l}\text { Political perception that the money is free } \\
\text { government money }\end{array}$ & 2 & 40.0 \\
\hline $\begin{array}{l}\text { No clear mechanism on how to deal with } \\
\text { defaulters }\end{array}$ & 2 & 40.0 \\
\hline Poor monitoring and evaluation & 3 & 60.0 \\
\hline Total & 12 & 240 \\
\hline
\end{tabular}

Table 4.5 indicates that all the five factors contributed to high default rate with lack of resources being the main factor.
This indicates that if adequate resources are allocated to the management team, it can curb the high default rate.

\subsection{Facts to Reduce the High Default Rate in C-YES}

Table 4.6 indicates that if capacity building among youths on financial management is done plus increasing loan amount, setting up legal framework on how to handle defaulter's allocation of adequate resources and timely release of cheques can reduce the high default rate in C-YES. On the other hand capacity building among the youths will equip them with the necessary skills to manage their businesses effectively and be able to repay their loans.

Table 4.6. Facts to Reduce the High Default Rate in C-YES

\begin{tabular}{lll}
\hline How to reduce default rate & Frequency & Percentage (\%) \\
\hline $\begin{array}{l}\text { Capacity building among youths } \\
\text { on financial management }\end{array}$ & 1 & 20.0 \\
$\begin{array}{l}\text { Increase loan amount } \\
\text { Set up legal framework on how to }\end{array}$ & 1 & 20.0 \\
handle defaulters & 1 & 20.0 \\
Allocation of adequate resources & 1 & 20.0 \\
Timely release of cheques & 1 & 20.0 \\
Total & 5 & 100.0 \\
\hline
\end{tabular}

\subsection{Resources to Perform YEDF Activities}

Table 4.7 shows that $100.0 \%$ of the respondents indicated that there are no adequate resources to perform YEDF activities. Inadequate resources like funds to the management team has been cited as one of the factors that affect loan repayments and if not addressed it may lead to it's eventual total collapse of the fund.

Table 4.7. Adequate Resources to Perform YEDF Activities.

\begin{tabular}{lll}
\hline Yes/No & Frequency & Percentage $(\boldsymbol{\%})$ \\
\hline NO & 5 & 100.0 \\
YES & 0 & 0.0 \\
TOTAL & 5 & 100.0 \\
\hline
\end{tabular}

\subsection{Follow-up on C-YES Without Adequate Resources}

Table 4.8. Follow Up on C-YES Without Adequate Resources.

\begin{tabular}{lll}
\hline $\begin{array}{l}\text { How officers follow up on } \\
\text { C-YES }\end{array}$ & Frequency & Percentage (\%) \\
\hline $\begin{array}{l}\text { Stopped follow ups } \\
\text { Talking to youths and } \\
\text { persuading them }\end{array}$ & 4 & 80.0 \\
$\begin{array}{l}\text { Through provincial } \\
\text { Administration }\end{array}$ & 2 & 40.0 \\
$\begin{array}{l}\text { Using opinion leaders and } \\
\text { influential people }\end{array}$ & 3 & 60.0 \\
Total & 2 & 40.0 \\
\hline
\end{tabular}

Table 4.8 indicates that $40 \%$ of the respondents use opinion leaders and influential people, $60 \%$ use Provincial administration, $40 \%$ talk to the youths and persuade them to pay while $80 \%$ stopped follow-ups. This could be one of the reasons as to why there is high default rate in C-YES. Follow-up of loans is very crucial in loan repayment as is 
keeps the borrowing units on their alertness and guiding them to rectify their mistakes in the first opportunities or extending them a helping hand in tiding over their tight times.

\subsection{Time Taken Between Application and Receiving of Funds}

Majority of the respondents represented by $96.0 \%$ of the 101 youth respondents indicated that it took them above 5 months between application and receiving of funds while $4.0 \%$ indicated that it took between 2 months -3 months between application and receiving of funds. The long duration taken to receive funds is likely to adversely affect majority of youths who are in farming. In turn this also affects the repayment because the loan beneficiaries are expected to use the proceeds from the activities that they are undertaking to repay the loan.

Table 4.9. Time Taken Between Application and Receiving of Funds

\begin{tabular}{lll}
\hline $\begin{array}{l}\text { Time Taken between application and } \\
\text { receiving of funds }\end{array}$ & Frequency & Percentage (\%) \\
\hline 2 months -3 months & 4 & 4.0 \\
Above 5 months & 97 & 96.0 \\
Total & 101 & 100.0 \\
\hline
\end{tabular}

\subsection{Effects of the Mentioned Duration on Youth's Businesses}

As regards the effects of the duration taken between application and receiving of funds $56.4 \%$ indicated that it led to collapse of the business, $11.9 \%$ indicated that there was poor market while $9.9 \%$ incurred losses. Others gave various reasons clearly indicating that the long duration negatively impacted on their businesses. This is indicated in table 4.10.

Table 4.10. Effects of the Mentioned Duration on Youth's Businesses

\begin{tabular}{lll}
\hline Duration & Frequency & Percent (\%) \\
\hline Collapse of the business & 57 & 56.4 \\
Delay in loan disbursement & 1 & 1.0 \\
Delay in starting of the business & 1 & 1.0 \\
Group collapsed during this period & 1 & 1.0 \\
Lack of market & 1 & 1.0 \\
Led to poor harvest & 1 & 1.0 \\
Members became impatient & 9 & 8.9 \\
Mistrust among members & 2 & 2.0 \\
Poor harvest & 2 & 2.0 \\
Poor market & 12 & 11.9 \\
The delay led to late planting & 3 & 3.0 \\
We incurred loss & 10 & 9.9 \\
Withdrawal of members & 1 & 1.0 \\
Total & 101 & 100.0 \\
\hline
\end{tabular}

\section{Conclusions and Recommendations}

Based on the findings from the study, it concludes that youth entrepreneurs are ready to grow if supported to grow and expand. It was noted that Constituency Youth Enterprise Scheme (C-YES) is faced with numerous challenges in its attempt to empower the youths and sustain itself in repayment. Availability of resources which includes funding was identified as a main factor affecting the repayment of the Constituency Youth Enterprise Scheme (C-YES). It was established that some officers stopped completely to follow-up on C-YES defaulters due to lack of funds. Government policies on government micro-credit are only on papers and not implemented at all and this makes it even worse when it comes to following up of defaulters.

Most of the respondents felt that a long time was taken between application and receiving of funds which impacts negatively on their businesses. Most of the youths are mainly in Agriculture and do not diversify. In case they receive the funds late and start farming, challenges in climatic conditions adversely affects them and this in turn affects their ability to repay the loan. There is need to adequately train them to diversify and venture into other areas.

The researcher suggests that further research be done to; investigate the sustainability of Constituency Youth Enterprise Scheme in Kenya., to assess the impact of the Youth Enterprise Development Fund on the lives of Kenyan youths and to establish whether the findings are similar to those generated by this study.

\section{References}

[1] Alok Majumdar, (Dec.2000), Recovery Blues, Treasury Management pp.46-49.

[2] Bryson,J.M.,(1989), Strategic Planning for Public and NonProfit Organizations, Jossey-Bass publishers.

[3] Economic Times \& CMIE, (Dec. 2000), Special Presentation Copy pp. $45-46$.

[4] Fackler, Martin (2008-10-23), "Trouble Without Borders". The New York Times.

[5] George Cherian \& Mayur Shetty, (Sept. 2000), As Good As it Gets, Money \& Banking, The Economic Times pp.7

[6] GOK, (2003), Economic Recovery Strategies for Wealth and Employment Creation, Nairobi; Government Printers.

[7] Group From Global Financial Crisis, (July 1999), Asian Development Bank Some Aspects \& Issues relating to NPAs in Publications G.P. Muniappan, (Jan-Mar. 2003), Money \& Finance, pp. $64-69$.

[8] Hamel, Gary, (2002), Leading the Revolution, Plume-Penguin Books/.New York.

[9] Hubbard, D and Bolles,D (2007), The Power of Enterprises Wide Project Management, Amacom,USA.

[10] Kitching Galvin (1980), Class and Economic change in Kenya: Yale University press London

[11] Kothari,(1990), Research Methodology Methods and Techniques,2nd Ed,Wishwa Prakasshan,New Delhi

[12] Landale, (2006), Advanced Techniques for Training and Development, 1st Ed, Gower,UK.

[13] Law of the Committee on the Judiciary, (July 17, 2007), 110th Congress, First Session, Washington: U.S. G.P.O. 
[14] Macharia D, (2009), From Theory to Actions: The Umtapo Experience in Youth Empowerment, Umtapo South Africa.

[15] Ministry of Youth Affairs, Issue No.1 (2007), Vijanaa Magazine.

[16] Ministry of Youth Affairs, (2006), Draft Strategic Plan (2006-2011) Government Printers, Nairobi.

[17] Mugenda O.M Mugenda A.G, (1999), Research Methods Quantitative and Qualitative Approaches, Acts Press, Nairobi Kenya

[18] M.S.A. Rao, (July 2001), A Better Future for Banks, Indian Management pp. 1 4-16.

[19] M.Y. Khan, (Feb. 2000), How to Tackle Credit Defaults, Business Line pp 6.

[20] Nacheket Mor \& Bhavana Sharma, (Sept. 2002), Rooting Out NPAs, ICICI Research Center.Org.

[21] Ochieng W.R (1985), A History of Kenya: Macmillan London.

[22] Odinga O, (1967), Not Yet Uhuru. Heinmann London

[23] Ogot B.A. \& Ochieng W.R, (1996), Decolonization and Independence in Kenya 1940 - 1993: East African Education Publishers, Kenya.

[24] Osborn,Hunder and Schermesrhon, (2003), Organizational Behaviours,8th Ed, ,John Wiley and Son's Incorporation ,USA.

[25] Republic of Kenya,(2005), Sessional Paper No. 2 on Development of Micro and
[26] Small Enterprises for Wealth and Employment- Creation for Poverty Reduction, Government Printer, Nairobi.

[27] Robertson, Justin, (2008), 1972- US-Asia Economic Relations: a Political Economy of Crisis and the Rise of New Business Actors. Routledge.

[28] Schindler and Cooper, (2003), Business Research Method 8th Edition, Tata Mc.Graw Hill, New Delhi.

[29] Soros, George, (2008), The New Paradigm for Financial Markets - The Credit Crisis of 2008 and What it Me PAs Grossly Mis-understood, Business Indiaans, New York: Public Affairs. ISBN9781586486839.

[30] Torbat, Akbar E. (2008-10-13). "Global Financial Meltdown and the Demise of Neoliberalism". Global Research (Center for Research on Globalization).

[31] United States Congress, (2008), Working Families in Financial Crisis: Medical Debt and Bankruptcy. Hearing Before the Subcommittee on Commercial and Administrative

[32] UNDP, (2000), Human Development Report, New York, Oxford University Press.

[33] Westland, J (2007), The Project Management Life Cycle, Kogan page,USA.

[34] Woods, Thomas E., (2009), A Free-Market Look at Why the Stock Market

[35] Collapsed, the Economy Tanked, and Government Bailouts Will Make Things Worse Regnery Publishing ISBN 1596985879. 